\title{
Valuing Species: The Continuities between Non-Market and Market Valuations in Biodiversity Conservation
}

\author{
Aurora Fredriksen
}

\begin{abstract}
This article explores how the rise of new markets for biodiversity has been facilitated by existing, non-market-based valuation practices within the field of biodiversity conservation. Where others have considered biodiversity markets in terms of capitalist and/or neoliberal expansion, I argue that the abstraction of the value of living things in markets is made easier by the existing valuation practices of species-based biodiversity conservation. After briefly contextualising the terms 'species' and 'biodiversity' within the history of Western conservation, the article shows how biodiversity conservation-as science, policy and practice-subordinates the value of individual living organisms and emplaced ecologies to the abstract categories of species and habitat types. This conceptual move performs a condition of ethical commensurability between individual organisms and places, thereby prefiguring the equivalence of value between units of the same category needed to establish new markets for biodiversity. The article considers this link between the valuation practices of species-based biodiversity conservation and new markets for biodiversity as an instance of performative continuity. The article concludes by reflecting on the critical use of attending to the links between existing valuation practices in biodiversity conservation and new biodiversity markets.
\end{abstract}

Key words: biodiversity conservation; species; valuation; markets; performativity

In this current decade-designated by the UN as its 'decade on biodiversity' - the idea of valuing 'Nature' in economic terms has risen to prominence on national and global agendas (see ten Kate and

Aurora Fredriksen, School of Environment, Education and Development, The University of Manchester, aurora.fredriksen@manchester.ac.uk

(C) 2017 Authors

LiU Electronic Press, DOI 10.3384/VS. 2001-5992.175139

http://valuationstudies.liu.se 
Crowe 2014; Helm 2015) and in popular media representations of the value of nature (e.g. Adler 2013; Juniper 2013). In one of the fullest realisations of this move towards the economic valuation of nonhuman nature, new markets for biodiversity offsetting have started appearing as part of environmental governance and corporate responsibility schemes (see BBOP 2016). Excellent existing research on biodiversity offsetting has explored the how of new market-based valuations of biodiversity-the calculative manoeuvres, acts of abstraction and performative framings involved (e.g. Robertson 2012; Sullivan 2013a; 2014; Carver 2015; Carver and Sullivan forthcoming). As with other novel domains of economisation and marketisation, a number of scholars attribute this rise in market-based valuations of nature to advancing neoliberalisation and/or capitalist expansion into new frontiers (e.g. Brockington and Duffy 2011; Büscher and Fletcher 2015). By focusing on forces advancing from the outside, however, these arguments fail to recognise the ways in which the existing, nonmarket valuation practices in the field of biodiversity conservation have not simply been pushed aside, but have paved the way for the entry of new market-based valuations. In this article I argue that the rise of market-based valuations in the field of biodiversity conservation is not only a marker of advancing capitalism or neoliberalism, but also an extension of the ongoing orderings and reiterative performances of the non-market-based valuations of living things in the field of biodiversity conservation. That is, the rationalising and universalising aspirations of biodiversity conservation (as a hegemonic framework for guiding conservation science, policy and practice), already enact the values of living organisms and emplaced ecologies through the abstract categories of species and habitats, effecting a commensurability between places and things that facilitates new market-based valuation practices.

More specifically, I argue that biodiversity conservation-as science, policy and practice-abstracts the value of living organisms and emplaced ecologies from individuals and their irreducibly complex relations within emplaced lifeworlds, locating it instead at the level of the categories of species and habitats. This conceptual move, in turn, performs a condition of ethical commensurability between individual organisms and places, thereby prefiguring the equivalence of value between units of the same category needed to establish new markets for biodiversity. The article works through this argument as follows: after brief sections introducing biodiversity offsetting markets and contextualising the concepts of biodiversity and species, I look at the work that biodiversity conservation does to order the unruly proliferation of life on earth into abstract, universalising categories of species and habitat units, setting up the condition of exchangeability required by new biodiversity markets. I then consider the performative continuity between these prior, non-market valuation practices of 
biodiversity conservation that locate the value of organisms and ecologies in abstract species and habitat units and new, market-based valuations in biodiversity markets. A concluding section briefly reflects on what attention to the links between existing valuation practices in biodiversity conservation and the rise of new biodiversity markets can add to critiques of the latter.

Before proceeding, there are a few things to note. First, in referring to biodiversity conservation, I mean to indicate the currently hegemonic assemblage ${ }^{1}$ of mainstream biodiversity conservation policy and practice informed by the science of conservation biology (see Brockington et al. 2008; Braverman 2015a). Although they are not discussed here, there are, of course, other contemporary modes of wildlife conservation that involve different practices of valuation (see Marris 2011), including ones that perform value through care and responsibility for individual living organisms and particular places (e.g. van Dooren 2014) and ones that foster unruly becomings (e.g. Lorimer and Driessen 2013). Second, this article tends towards a focus on animals rather than other living organisms like plants, fungi or the great variety of single celled living organisms. This choice in part mirrors the priorities of biodiversity conservation, but it also mirrors my own interests in the ethics of our (human) relations with nonhuman animals (Fredriksen 2016; see also Haraway 2008; van Dooren 2014; Despret 2016).

\section{New Markets for Biodiversity}

In recent years, new markets for biodiversity have emerged in the form of species banks and offsetting schemes (see Fox and Nino-Murcia 2005; Benabou 2014; ten Kate and Crowe 2014). As in other areas where economic values are being assigned to non-human nature (see Helm 2015 for an extensive review of 'natural capital'), to achieve the commensurability between particular organisms and places necessary for exchange, the irreducible complexity (Braun 2008) of emplaced ecologies must be simplified and differences between individuals of the same species obscured. Indeed, a growing body of scholarship explores how new markets for biodiversity employ a great deal of simplification and abstraction in order to render bits of nature exchangeable with one another (e.g. Robertson 2012; Sullivan 2013a, 2013b; Carver and

1 I use 'assemblage' here following from the French 'agencement' (see, generally, Deleuze and Guattari 1987; Callon 2007), to indicate a coming together of things 'which are simultaneously human and nonhuman, social and technical, textual and material-from which action springs' (MacKenzie et al. 2007: 14-15). While the assemblage concept is often used to highlight emergence, multiplicity and indeterminacy-disordering - this incessant becoming is only one possible dynamic of an assemblage (Anderson and McFarlane 2011: 124). Assemblages may also tend towards stabilisation, normalisation and repetition-ordering (Dewsbury 2011). 
Sullivan forthcoming). The consequences of this simplification and abstraction, in turn, have been criticised for the disposability they impose on actually living things and the associated ethical inadequacy of such responses to ecological destruction (see Yusoff 2011; Sullivan 2017).

Sian Sullivan's (2013b) discussion of the proposed offsetting scheme for barbastelle bats (Barbastella barbastellus) in southern England exemplifies this last point: in this case the proposed construction of a new power plant involving the degradation of a habitat where barbastelle bats currently live is proposed to be offset by the restoration of bat habitat at a future date, but, as Sullivan writes, '[i]t is difficult to know what the bats should do during the time lag between habitat impacts and on-site habitat creation' (Sullivan 2013b: 90). The suffering or death of individual barstabelle bats, however, is not a matter of concern for biodiversity offset markets: the ordering of individual living barstabelle bats and the great variety of emplaced ecological relations in which they are entangled into species and habitat units allows them to be exchanged with other individual animals categorised into the abstract species unit of $B$. barbastellus and other places framed as equivalent habitat units. Despite the violence done to actual lives, biodiversity offsets appear to satisfy the interests of marketised biodiversity conservation by performing a 'zero-net-loss' in pecuniary biodiversity conservation value (Sullivan $2013 \mathrm{~b}$ ). Thus, Sullivan concludes that this marketised version of biodiversity conservation works to devalue the lives of the actually living individual bats that will be displaced and possibly face death in the interval between habitat destruction and habitat 'restoration' (ibid.).

Research like Sullivan's is indispensable for showing the disturbing efficiency with which new biodiversity markets devalue actually living things and render individual animals killable. At the same time, in the spirit of further exploring these processes, I suggest that the way in which new biodiversity markets devalue actually living, individual organisms and make them killable is a difference in degree rather than kind from contemporary non-market biodiversity conservation practices. This is because the non-market-based valuations of biodiversity conservation also devalue individual animal lives and render them exchangeable for others of the same kind. In other words, the rise of market-based valuations of living things in new biodiversity markets can only partly be attributed to the incursion of economic values from outside of the biodiversity conservation assemblage (e.g. Büscher and Fletcher 2015); this is because the ability of economic values to gain purchase in the field of biodiversity conservation has been facilitated by the quality of exchangeability between individual living things already enacted by the non-economic, non-market-based valuations generated from within the biodiversity conservation 
assemblage. As a first step in exploring the links between the noneconomic valuations of living entities generated within the discourses and practices of biodiversity conservation and the economic valuation of animal lives in new markets for biodiversity, the following section briefly situates the concepts of 'biodiversity' and 'species'.

\section{Biodiversity and Species in Conservation}

While biodiversity conservation expressly locates value at three levels - species, genes and ecosystems-it is the species category, as Irus Braverman observes, that serves as 'the foundational ontological unit' by which life is known and calculated within conservation biology, the scientific discipline that informs biodiversity conservation (2015b: 185; see also Braverman 2015a; Lorimer 2015). It is not that genes and ecosystems don't garner significant attention as loci of value in biodiversity conservation, but rather that value at these levels is often calibrated in relation to the value of relevant species categories. This is apparent in the case of genetic diversity, which is valued in biodiversity conservation to the degree that it is useful for propagating valued species (Friese 2015), a point underlined by the framing of the value of preserving diverse genetic types in living populations or frozen 'gene banks' as an 'insurance policy' for endangered species (Soulé et al. 1986). Ecosystems, meanwhile, are increasingly being valued for the 'services' they provide for human society and economy (see Helm 2015). However, within biodiversity conservation (versus other versions of environmental science and governance) their value is still often framed as an effect of their ability to support a diversity of species (see, for example, EEC 1992). Alternately, the species category is sometimes promoted within biodiversity conservation as a foundational unit of genetic and ecosystem value, as when the IUCN describes species as 'the bearers of genetic diversity and the building blocks of ecosystems' (IUCN Red List n.d.). As well as the foundational ontological unit, then, the category of species also serves as a locus, and basic unit, of non-economic value in biodiversity conservation. Before exploring how this shaping of non-economic value facilitates market-based valuations in biodiversity conservation in more detail, however, it is useful to briefly contextualise the modern biodiversity conservation apparatus.

The primacy of the biodiversity concept and its associated use of the species unit as a universal, rationalising category for valuation is a relatively recent way of ordering the conservation of non-human nature. Early iterations of the modern conservation movement in late nineteenth-century North America were concerned with the specificities of the places and animals targeted for protection, attaching agency as sublime power to particular places and agency to some individual animals in various romantic (generally hunting-related) 
narratives (Cronon 1996; see Taylor 2016 for a detailed history of this early iteration of conservation). As conservation became more scientifically oriented in the twentieth century, however, the focus began to shift from particular places to generalisable types of habitats and from specific emplaced groups of animals to biologically defined species. Through the 'Earth Day era' of the 1970s (Lemann 2013), however, the general categories of habitats and species continued in much of Western conservation practice to be focused through the particular: particular cases of emplaced environmental harm or threat, and on the tangible and affective connections between individuals and particular places and animals (see Rome 2013 on the tangibility of conservation causes in the 1970s; Lockwood 2012 on the 'affective legacy' of Silent Spring, a seminal conservation text from this period). The shift from places and animals to habitats and species, from the particular to the universal, was only more fully realised in subsequent decades with the rise of biodiversity as an organising force in conservation science and policy.

Brought to public attention by a group of scientists in the mid-1980s, the concept of biodiversity (short for 'biological diversity') was rapidly taken up in conservation discourse and practice following the signing of the UN Convention on Biological Diversity at the Rio Earth Summit in 1992 (CBD n.d.). Denoting the variety of life on earth at the level of species, genes and ecosystems (ibid.), biodiversity was first promoted as an organising framework for conservation science and policy as a means of rationalising its theretofore widely variable, piecemeal approaches to saving species (Takacs 1996). In other words, it was an express attempt to move away from the particular and affective impulses driving earlier conservation practices. Acting as what Bruce Braun (2006) calls a 'global nature' (see also Lorimer 2015), the biodiversity concept thus proposes a universal way to assess, rank and respond to-and thereby to value-conservation problems. In locating 'biodiversity value' at the level of species, genes and ecosystem types (CBD n.d.), biodiversity conservation seeks to rationally order organisms and emplaced ecologies into abstract categories that serve as separable and comparable units, which can then be rationally compared and evaluated to direct conservation action (Barad 2003; Lorimer 2015). By providing a universal language for discussing, and a framework for rational comparison of, nonhuman organisms and the ecologies where they live, the biodiversity concept attempts to remove the subjective, leaving behind what Jonathan Franzen (2015) calls the 'novelistic' character of conservation - that is, the particular, place-specific and affective, wherein 'No two places are alike, and no narrative is simple' (ibid.). To achieve this, biodiversity frames out the lively agencies of individual living animals in their particular interconnections with specific places, replacing the 
irreducible complexities of individual organisms and specific places with the more manageable categories of 'species' and 'habitats'.

With its origins in Platonic forms and subsequent metaphysical systems of classification and taxonomy (Ghiselin 1997), the concept of species as it appears in biodiversity conservation is variously based on grouping organisms according to biological understandings of genetic or morphological similarities, evolutionary lineages and/or reproductive compatibilities. Critically, as Audra Mitchell (2016: 26) points out, despite differing on the specifics, these competing ways of defining species 'all treat species as categories that transcend the organisms, cells or genes that compose them, and that maintain integrity despite the perishing of these components'. Thus the species concept positions the worth of individual animals within the same species category as subordinate to the transcendent species type (Ansell-Pearson 1999; Smith 2014). This positioning, in turn, engenders a biopolitical dynamic within biodiversity conservation wherein governance techniques and technologies of administration and scientific expertise are used to separate valued lives from unvalued ones in pursuit of securing life at the level of species (on biopolitics generally see Foucault 2003; on biopolitics in conservation see for example Chrulew 2011; Friese 2013; Lorimer and Driessen 2013; Biermann and Mansfield 2014; Braverman 2015a, 2015b; Lorimer 2015; Fredriksen 2016). The following sections now turn to the question of how this positioning of value at the level of species is achieved in the valuation practices of biodiversity conservation.

\section{The Ordering of Immanence in Biodiversity Conservation}

The irreducible complexity and incessant movement of living ecosystems has been pointed out by various natural scientists interested in modes of thought such as complexity and uncertainty theories and non-equilibrium ecology (see DeLanda 2009 for an overview), as well as by the growing group of social theorists interested in vital materialities (e.g. Bennet 2010; Ingold 2011), relational ontologies (e.g. Law and Mol 2011; Latour 2016), and other more-than-human approaches (e.g. Braun 2008; Hinchliffe 2008; Lorimer 2012). These works all suggest that the trajectories of life, both human and non-human, are not wholly knowable in advance, but unfold in unpredictable 'manifold lines of becoming' (Ingold 2012: 347). This focus on immanence, whereby things and their character are never fixed, but always in the process of becoming (see Deleuze and Guattari 1987; Deleuze 1988; Massey 2005), challenges the ontological positivism assumed by biodiversity conservation's stable species and habitat units. Rather than the relatively stable and distinct types posited by the species category, an ontology of immanence 
directs attention to the ongoing processes and unruly mixings of inventive life (Hinchliffe 2008; van Dooren 2014; Fredriksen 2016). The premise of immanence and its implication of life's inherently disordering tendencies to 'become otherwise' (Lorimer and Driessen 2013: 255; after Deleuze and Guattari 1987), however, do not foreclose the possibility that such immanence can be subject to reigning in and systematic denial through the orderings enacted by biodiversity conservation assemblages.

\section{Pacifying lively agencies}

In his work on economisation and marketisation, Michel Callon shows how entities brought into market relationships for exchange ('marketized') must be actively defined and valued (Çalıskan and Callon 2010). In the process of this defining and valuing, a divide is enacted and reproduced between "the "things" to be valued and the "agencies" capable of valuing them' (ibid.: 5). As all entities involved are understood to have certain capacities depending on their relational entanglement with other entities, those that are to be valued for exchange in this divide must first have their agencies 'pacified': rendered stable so they are amenable to standardised calculations for exchangeability (ibid.). On the other side of this enacted divide are those entities with the capacity for calculating the value of that which is pacified. Which entities are pacified and which are enacted as capable of pacifying is a matter of the unequal distribution of power within market assemblages (ibid.).

The pacification of lively entities for exchange on biodiversity markets involves ordering market spaces such that certain things are emphasised within the frame of the market and others left out of or actively excluded from this frame (Hinchliffe et al. 2007; Sullivan and Hannis 2014). In conventional economics, the latter are referred to as externalities. The economic imagination of externalities is one that revolves around the categories of costs and benefits: if something is left out of a market it is either a cost or a benefit to some party outside that market. However, in recognition that many of the things framed out of markets cannot be readily understood as either costs or benefits -indeed, by virtue of their being left out of the frame many have not yet been subject to the processes of economisation by which they would be framed as such-Callon (e.g. 2007) has argued that externalities might be better understood as 'overflows'.

This framing process is apparent in the shaping of values for organisms and ecologies in biodiversity offsetting and species banking markets. In these novel formations, the agencies of living habitats and animals must be pacified so that they can be rendered into units of commensurable values for exchange. To do this, the irreducible complexity of specific ecosystems and differences between individuals of the same species must be left out of the market framing (becoming 
overflows). However, while the valuations involved in biodiversity markets certainly advance this pacification process, they do not initiate it ex nibilo. Rather, they start from the species and habitat units established by biodiversity conservation, which already pacify the agencies of the lively organisms and irreducible complexities of ecological relationships that they represent.

\section{Ordering devices and non-market valuations in biodiversity conservation}

As noted above (see section on 'Biodiversity and Species in Conservation'), the valuation of animals in biodiversity conservation relies on the ordering of non-human animals into abstract species units. Categorising the great variety of living organisms and ecological relations into stable species and habitat categories renders these animals and ecologies systematically knowable, fixing them as subjects for scientific investigation and targets for generalisable policy actionpacifying them, in Callon's language (above). Indeed, assigning individual animals and ecologies to stable species and habitat categories, which can then be catalogued and ranked according to characteristics such as rarity or level of vulnerability, is one of the most prominent techniques by which biodiversity conservation establishes the relative value of different living things (Bowker 2005; Yusoff 2010). The IUCN Red List of Threatened Species ${ }^{\mathrm{TM}}$ (hereafter the IUCN Red List) is the largest and most influential of such catalogues, aspiring to consolidate and standardise knowledge of animals and ecologies on a global level, and thus serve as a universal tool for assessing the relative, non-economic values of different organisms and ecosystems in accordance with their position within a global picture of biodiversity (Braverman 2015b).

The work of ordering different organisms and habitats into generalised species and habitat categories for biodiversity cataloguing is significant. For a start, to be put into a species or habitat category, animals and ecologies have to be made present (Hinchliffe 2008). That is, they must be identified and described by science, assigned to a species or habitat category and enumerated. Notably the IUCN Red List is currently, in its own words, 'biased' towards animals rather than plants or fungi-not to mention single celled organisms like bacteria and protists-and, within the animal kingdom, towards terrestrial animals living in forest ecosystems (IUCN Red List n.d.). This speaks both to the way in which some organisms are more easily encountered by researchers, as well as to the persistence of non-rational, affective attachments to animals that are 'big like us' (Hird 2009) to the exclusion of 'unloved others' (Rose and van Dooren 2011).

Importantly, making things present in biodiversity catalogues (and therefore present as potential subjects of biodiversity conservation 
more generally), makes other things absent (Callon and Law 2004; Hetherington 2004). Organisms that are not easily encountered, subjected to scientific examination, or enumerated are less likely to be made present as targets for biodiversity conservation through catalogues and databases like the IUCN Red List. At the extreme, there are some organisms-primarily single celled bacteria and protistswhose qualities make them particularly resistant to identification and stabilisation into species units for biodiversity conservation (see Lorimer 2006; Haraway 2008; Friese 2010). In line with biodiversity conservation's ideal of rationalising conservation, however, the IUCN Red List aspires to overcome its current 'gaps' in coverage, listing expanding taxonomic and geographic coverage as the first 'key result' sought in its Strategic Plan 2013-2020 (IUCN Red List Committee 2013). There are some organisms, however, whose absences from the IUCN Red List and other devices for biodiversity conservation surveillance are not understood as gaps, but which are instead intentionally excluded as targets of biodiversity conservation. This group includes organisms that are framed as 'invasive', 'non-native' or hybrid (and therefore 'unnatural'), all of which are framed in biodiversity conservation discourse as valueless threats to valued life (e.g. van Dooren 2011; Atchison and Head 2013; Fredriksen 2016).

In sum, the species unit in biodiversity conservation acts to pacify the lively agencies of living things so that they can be ordered into bounded categories of more or less valued life. Individual organisms are framed as being either inside or outside of species units, and the unruly tendencies of organisms to mix and unfold beyond stable species categories as well as differences between individuals within a species category are excluded from this frame (Grosz 2004; Lulka 2004; Hinchliffe 2008; Bear 2011; Mitchell 2016). ${ }^{2}$ Biodiversity catalogues thus make organisms present for conservation by conceptually abstracting them from their messy lifeworlds and bringing them into stable species categories, which can be ranked according to various assessments of value, for example their rarity, phylogenetic distinctiveness, or level of endangerment. And, by positioning individual organisms as equivalent within species categories, biodiversity conservation's orderings pacify the agency of living things and establish the quality of interchangeability between individual living things that supports notions of commensurability

\footnotetext{
2 Although it should be noted that within some spaces of biodiversity conservation, such as labs and captive breeding programmes, certain differences between individuals within a species do come to matter, namely differences at the level of genes, which are used to mark individual organisms as being more or less valuable to the continued life of the species (e.g. Haraway 2008; Friese 2015). Within these spaces the value of individuals of the same genetic type are equivalent in much the same way that individuals within the same species category are positioned as having equivalent value in the spaces of biodiversity catalogues.
} 
necessary for exchange in species banking schemes and biodiversity offsetting markets. In other words, the ordering of life into the stable categories of species and habitats sets the stage for the market-based valuations of different organisms that circulate in new markets for biodiversity. This ordering, of course, is not simply a one-off achievement, it takes reiterative work. In such reiterative work, one can further detect a line of continuity linking new market valuations in biodiversity conservation with prior non-market valuations. The next section explores this reiterative work, considering it as an aspect of the performative quality of biodiversity conservation's valuation practices.

\section{The Performativity of Biodiversity Conservation}

Understanding the stabilisation of entities in terms of acts of 'performativity'-the proposition that reality is performed, or done, rather than observed (Mol 2002)-provides a further avenue for thinking through the links between market and non-market valuations in biodiversity conservation. As with the matter of pacifying agencies, the role of performativity in effecting values has been central to theorising economisation processes (e.g. MacKenzie et al. 2007). For Callon (1998) the concept is used to describe the ways in which economics and economists do not describe a pre-existing reality-'The Economy'-but instead participate in-'perform'-its making; they do so through their implication in the formatting of the relations between elements within assemblages that constitute markets and other economic entities (Callon 1998; Mitchell 2002; MacKenzie 2006; MacKenzie et al. 2007; Muniesa 2014). Similarly, in biodiversity conservation markets, assessments of the relative market values of different species and habitat types do not simply reflect some given reality about the relative worth of different species and habitats, but are actively involved in shaping these values (see Carver 2015; Carver and Sullivan forthcoming, for an exemplary case study of these processes). At the same time, as with pacifying agencies, biodiversity conservation markets do not performatively enact relative market values ex nibilo, but performatively reiterate the relative non-market values of species and habitats that are already being performed by non-market biodiversity conservation (see Butler 2010 for a longer discussion of the reiterative character of performativity). Thus the nonmarket values of habitats and species performed by biodiversity conservation will guide the market values: the habitats and species that are assigned high non-market values by conservation biology-for example due to their rarity or phylogenetic uniqueness-are those that will be assigned the highest market values in biodiversity offsetting markets (e.g. ten Kate and Crowe 2014). More fundamentally, market values in biodiversity conservation markets are performatively located at the level of species or habitat units, which reiterates the earlier performative locations of non-market value in biodiversity conservation. 
The performativity of species as the locus of value in biodiversity conservation is performed both discursively (as speech act) and through biodiversity conservation practices. Discursively, the day to day language of biodiversity conservation is one wherein species (rather than individuals) are the locus of moral concern and the target of action. Rather than referring to animals as groups of individuals, for example by saying that Amur leopards are threatened by habitat destruction, there is a tendency in both advocacy practices and conventional speech to say 'the Amur leopard' is threatened by habitat destruction, referring to the species whole rather than to individual imperilled lives. This effectuation of moral worth at the species, rather than the individual, level is captured by Justin Smith (2014: n.p.) in his astute observation that 'we say that the Steller's sea cow was hunted to extinction, in much the same way we might say that the vicar has succumbed to gout'. Such commonplace speech acts are one basic site where the value of individual animals is performatively subverted to the species unit (cf. Derrida 2008; Bear 2011).

The law is another discursive site where the value of animals is performatively located in abstract, clearly defined species types. Elsewhere (Fredriksen 2016) I have written about the conservation of Scottish wildcats, in which the unruly mixings of wildcats and feral domestic cats threatens to destabilise the whole endeavour. After decades (and likely centuries) of interbreeding, conservation biologists are finding it nearly impossible to reliably say whether an individual wild-living cat in Scotland is a 'pure' Scottish wildcat or a hybrid. The difficulty conservationists encounter in stabilising a species type to target for 'Scottish wildcat conservation', however, hasn't stopped conservationists from pressing on with ever more sophisticated efforts to separate valued wildcats from devalued hybrids and even more devalued feral domestic cats. This is not simply a matter of blind ideology (though there is some of that in the mix), but also a pragmatic response to the current legal environment which affords strict protection for Scottish wildcats but allows hybrid and feral cats to be shot on sight (ibid.). Indeed, such constraints in the wider governance of biodiversity conservation, prominently including national and international legal regimes, generally afford protection for animals only at the level of clearly defined species (Braverman 2015a), thus acting as another site where the value of animals and other organisms is performatively located at the level of species.

As well as these discursive iterations, the value of living organisms is also performatively located at the level of species rather than individuals through the many fleshy encounters of biopolitical practices within biodiversity conservation, including the management of animal populations through culling 'for the good of the species' (Lulka 2004; Smith 2014); captive breeding programmes that subject individual animals to confinement, invasive procedures, forced 
couplings, and euthanasia in the name of regenerating the species (Chrulew 2011; van Dooren 2014; Braverman 2015a); and the distribution of care and harm to individual organisms based on their categorisation as 'native' or 'invasive' species rather than an assessment of their particular actions and relationships (Marris 2011; van Dooren 2011).

Critically, in performatively subverting the value of individual organisms to the species unit, biodiversity conservation practices position individual animals as interchangeable with other individuals who are categorised as members of the same species. In deciding which animals are most representative of, or whose survival is most beneficial for, the species-and therefore most worthy of preservation-of course, biodiversity conservation experts and practitioners also performatively shape species. This is most evident in captive breeding programmes where animals are selected and bred according to stringent plans for maximising genetic diversity while maintaining an ideally designated and fixed species form (Haraway 2008; Braverman $2015 \mathrm{a}$; Fredriksen 2016) and in the subset of these programmes focused on genetic technologies, wherein animals who possess genetic types that 'don't "give back" to the population'-because they are common or 'redundant'-are characterised by those working in biodiversity conservation as embodying 'forms of waste' (Friese 2015: 165). The species category is also performatively shaped in biodiversity conservation practices in less immediate ways, as through the management of in situ populations of protected species with practices such as limiting spatial ranges, providing supplemental feeding, administering vaccines or other medications, and culling or sterilising 'problem' animals like hybrids or others that are perceived to threaten the viability of the ideal species form (Lulka 2004; Braverman 2015a; Fredriksen 2016).

The case of Hawaiian crows (Corvus hawaiiensis) provides one final and particularly evocative example of such performative valuation practices in biodiversity conservation. Van Dooren (2016) shows how the valuing of the Hawaiian crow species unit-as defined by a fixed, ideal genetic type-in captive breeding programmes is proceeding at the expense of particular crow cultures, which are not being-cannot be-learned in captive breeding sites. This loss is a low priority for the conservation of $C$. hawaiiensis, the species as a genetic type and on which biodiversity conservation places value. In Thom van Dooren's analysis this problematic focus on the species as defined through genetic type puts 'ways of being in the world ... at stake' (2016: 36). In terms of the present discussion, crow culture is being framed out of crow conservation and becomes an overflow from this conservation assemblage centred on the value of species (defined through genetic identity). While this overflow could destabilise the C. hawaiiensis conservation assemblage if, for example, lost crow cultures limit 
crows' ability to survive outside the captive breeding facility, it is perhaps more likely that it will not do so. Instead, the continued existence of animals with the genetic make-up of C. hawaiiensis in the world, whether wild-living or held indefinitely in captive facilities, will likely mark this conservation effort as a success through the hegemonic discourse of biodiversity conservation.

\section{Conclusion}

The framing of specific animals and places as commensurable species or habitat units in biodiversity markets renders them interchangeable with similarly framed units of equal value such that they can be swapped for another without losing value through the exchange. This new mode of valuation in biodiversity conservation, with its premise of 'zero-net-loss' has generated much thoughtful critique (e.g. Yusoff 2011; Büscher et al. 2012; Sullivan 2013b, 2017). As I have argued throughout this article, however, while the register of value-economic value circulated in biodiversity markets-is new to biodiversity conservation, the rendering of individual animals and places as units of species and habitats on which the commensurable values of new markets are based, is not. Rather, new markets for biodiversity conservation are new iterations of longer-standing performative valuings of animals in biodiversity conservation practice that subsume the value of individuals to that of the species.

This is not to argue that market iterations of biodiversity conservation are not more worrying than non-market iterations. New markets for biodiversity simplify and accelerate the performance of interchangeability between living entities and they promote a discourse that holds that if things are not assigned economic values then there is no way to prevent their degradation. Thus the deployment of economic valuation and markets in the field of conservation is often justified as the most viable way of making conservation 'count' (Helm 2015). The inverse of this narrative, of course, is that if things don't have economic value, they are worthless (see Sullivan 2014, 2017). Thus in new markets for biodiversity, the calculation of values for living things has the effect that 'paradoxically and against the avowed intent of those calculating, the valued entities which emerge, although more quantitatively defined ... [appear] more disposable than ever' (Bracking et al. 2014: 2). To return to the case of Sullivan's (2013b) barstabelle bats, for example, the proposed offset is designed in such a way that value is measured only at the point of exchange: the value of the bats being displaced or killed by the new development is calculated at the point of securing the offset and thus the lost value of the original bats paid for; the future fate of these bats and their potential replacements at the offset site will not retrospectively change the market values established at the point of exchange. 
It is clear that the market valuation of living things in biodiversity conservation markets heightens the risk that living organisms will be devalued through the very practices aimed at valuing them and should thus be resisted. What I have argued here, however, is that resisting the devaluation of living things and fostering relations of care and responsibility in conservation practice require more than resisting the economic valuation of living things in biodiversity conservation markets; they also require resisting the non-economic value orderings of biodiversity conservation that subordinate the value of individual living things to abstract species units and frame the irreducible complexities of emplaced ecologies as interchangeable habitat types. They require resisting the pull of the rational and universal and attending to the novelistic aspects of emplaced conservation-'staying with the trouble' to borrow from Donna Haraway (2016) — in order to encourage multispecies flourishing (Collard et al. 2015).

In exploring just one field where new economic valuations are gaining purchase-that of biodiversity conservation-this article has explored how attention to different types of valuation practices, economic or not, might help us to look more thoughtfully at ostensibly new forms of valuation, and their relationship to previous valuations, in other sites of newly economised public policy and environmental management. In this article I have identified a line of continuity between the modern scientific orderings and performativities of value at the abstract level of species and new market orderings of value in the field of biodiversity conservation. Investigation of other sites where novel market valuations are taking hold might turn up different relationships between existing and new valuation assemblages. But in all cases I suspect a careful unpacking of valuation practices of different types will prove useful in understanding what, exactly, is at stake and where resistance might most tactically be aimed.

Acknowledgements: The research on which this article is based has been supported by the project 'Human, non-human and environmental value systems: an impossible frontier?', led by Professor Sarah Bracking and gratefully funded by the Leverhulme Trust (award RP2012-V-041). I would like to thank Sarah Bracking and Sian Sullivan for their support and comments on an early version of this article, as well as the two anonymous reviewers and the editors of Valuation Studies for their very useful guidance in revising the article into its current, much improved, form. 


\section{References}

Adler, Simon (producer). 2013. "Worth: How do you put a pricetag on nature?" Radiolab [audio podcast], season 13, episode 3. http:// www.radiolab.org/story/worth/, accessed 20 May 2016.

Anderson, Ben, and Chris McFarlane. 2011. "Assemblage and Geography." Area 43(2): 124-127.

Ansell-Pearson, Keith. 1999. Germinal Life: The Difference and Repetition of Deleuze. London and New York: Routledge.

Atchison, Jennifer, and Lesley Head. 2013. "Eradicating Bodies in Invasive Plant Management." Environment and Planning D 31: 951-968.

Barad, Karen. 2003. "Post-Humanist Performativity: Toward an Understanding of How Matter Comes to Matter." Signs 28(3): 801-831.

BBOP (Business and Biodiversity Offsets Programme). 2016. The Business and Biodiversity Offsets Programme (BBOP): planning policies and projects to achieve a net gain of biodiversity. BBOP Vision, Mission, Goals, Strategy, Plan. Approved by the BBOP Advisory Group and adopted by the Executive Committee on 20 January. http://www.foresttrends.org/documents/files/doc_5091.pdf, accessed 15 December 2016.

Bear, Christopher. 2011. "Being Angelica? Exploring Individual Animal Geographies.” Area 43(3): 297-304.

Benabou, Sarah. 2014. "Making up for Lost Nature? A Critical Review of the International Development of Voluntary Biodiversity Offsets.” Environment and Society 5: 102-123.

Bennett, Jane. 2010. Vibrant Matter: A Political Ecology of Things. Durham, NC: Duke University Press.

Biermann, Christine, and Becky Mansfield. 2014. "Biodiversity, Purity, and Death: Conservation Biology as Biopolitics." Environment and Planning D: Society and Space 32: 257-273.

Bowker, Geoffrey C. 2005. "Time, Money and Biodiversity." In Global Assemblages: Technology, Politics, and Ethics as Anthropological Problems, edited by Aihwa Ong and Stephen J. Collier, 107-123. Oxford: Blackwell.

Bracking, Sarah, Patrick Bond, Dan Brockington, Bram Büscher, James Igoe, Sian Sullivan, and Phil Woodhouse. 2014. "Initial Research Design: 'Human, Nonhuman and Environmental Value Systems: An Impossible Frontier?'” LCSV Working Paper Series, No. 1. Manchester: University of Manchester.

Braun, Bruce. 2006. "Environmental Issues: Global Natures in the Space of Assemblage." Progress in Human Geography 30(5): 644-654.

—. 2008. "Environmental Issues: Inventive Life." Progress in Human Geography 32(5): 667-679.

Braverman, Irus. 2015a. Wild Life: The Institution of Nature. Stanford, CA: Stanford University Press.

- 2015b. "En-Listing Life: Red Is the Color of Threatened Species Lists." In Critical Animal Geographies: Politics, Intersections and 
Hierarchies in a Multispecies World, edited by Rosemary-Claire Collard and Kathryn Gillespie, 184-202. London: Routledge.

Brockington, Dan, and Rosaleen Duffy (eds). 2011. Conservation and Capitalism. Oxford: Wiley-Blackwell

Brockington, Dan, Rosaleen Duffy, and James Igoe. 2008. Nature Unbound. London: Earthscan.

Büscher, Bram, and Robert Fletcher. 2015. "Accumulation by Conservation.” New Political Economy 20: 273-298.

Büscher, Bram, Sian Sullivan, Katja Neves, James Igoe, and Dan Brockington. 2012. "Towards a Consolidated Critique of Neoliberal Conservation." Capitalism, Nature, Socialism 23(2): 4-30.

Butler, Judith. 2010. "Performative Agency." Journal of Cultural Economy $3(2): 147-161$.

Çalıskan, Koray, and Michel Callon. 2010. "Economization, Part 2: A Research Programme for the Study of Markets.” Economy and Society 39(1): 1-32.

Callon, Michel. 1998. "Introduction: The Embeddedness of Economic Markets in Economics." In The Laws of the Markets, edited by Michel Callon, 1-57. Oxford and Malden, MA: Blackwell/Sociological Review.

- 2007. "What Does It Mean to Say That Economics Is Performative?" In Do Economists Make Markets? On the Performativity of Economics, edited by Donald MacKenzie, Fabian Muniesa, and Lucia Siu, 311-357. Princeton, NJ: Princeton University Press.

Callon, Michel, and John Law. 2004. "Guest Editorial Introduction: Absence - Presence, Circulation, and Encountering in Complex Space." Environment and Planning D: Society and Space 22(1): 3-11.

Carver, Louise. 2015. "Measuring the Value of What? An Ethnographic Account of the Transformation of 'Nature' under the DEFRA Biodiversity Offsetting Metric.” LCSV Working Paper Series, no. 11. Manchester: University of Manchester.

Carver, Louise, and Sian Sullivan. forthcoming. "Creating 'Good Biodiversity Yield per Hectare'? How Economic Contexts Shape Technical Calculations in Biodiversity Offsetting." Conservation Biology.

CBD (Convention on Biological Diversity). no date. "About Biodiversity", CBD website. https://www.cbd.int/2011-2020/about/biodiversity, accessed 15 December 2016.

Chrulew, Matthew. 2011. "Managing Love and Death at the Zoo: The Biopolitics of Endangered Species Preservation." Australian Humanities Review 50: 137-157.

Collard, Rosemary-Claire, Jessica Dempsey, and Juanita Sundberg. 2015. "A Manifesto for Abundant Futures." Annals of the Association of American Geographers 105(2): 322-330.

Cronon, William. 1996. "The Trouble with Wilderness, or Getting Back to the Wrong Nature." In Uncommon Ground: Rethinking the Human Place in Nature, edited by William Cronon, 69-90. New York: W.W. Norton. 
DeLanda, Manuel. 2009. A New Philosophy of Society: Assemblage Theory and Social Complexity. London and New York: Continuum.

Deleuze, Gilles. 1988. Bergsonism. New York: Zone Books.

Deleuze, Gilles, and Félix Guattari. 1987. A Thousand Plateaus: Capitalism and Schizophrenia. Trans. B. Massumi. London: Continuum.

Derrida, Jacques. 2008. The Animal That Therefore I Am. Trans. MarieLouise Mallet. New York: Fordham University Press.

Despret, Vinciane. 2016. What Would Animals Say If We Asked the Right Questions? Minneapolis, MN: University of Minnesota Press.

Dewsbury, J-D. 2011. "The Deleuze-Guattarian Assemblage: Plastic Habits." Area 43(2): 148-153.

EEC (European Economic Community). 1992. Council Directive 92/43/EEC of 21 May 1992 on the conservation of natural habitats and of wild fauna and flora. http://eur-lex.europa.eu/legal-content/EN/TXT/? uri=CELEX:31992L0043, accessed 10 December 2016.

Foucault, Michel. 2003. Society Must Be Defended: Lectures at the College de France, 1975-1976. London: Allen Lane.

Fox, Jessica, and Anamaria Nino-Murcia. 2005. "Status of Species Conservation Banking in the United States." Conservation Biology 19(4): 996-1007.

Franzen, Jonathan. 2015. "Carbon Capture." The New Yorker April 6. http:// www.newyorker.com/magazine/2015/04/06/carbon-capture, accessed 10 September 2016.

Fredriksen, Aurora. 2016. "Of Wildcats and Wild Cats: Troubling SpeciesBased Conservation in the Anthropocene." Environment and Planning D: Society and Space 34(4): 689-705.

Friese, Carrie. 2010. "Classification Conundrums: Categorizing Chimeras and Enacting Species Preservation." Theory and Society 39(2): 145-172.

- 2013. Cloning Wildlife: Zoos, Captivity, and the Future of Endangered Animals. New York: New York Univerity Press.

- 2015. "Genetic Value: The Moral Economies of Cloning in the Zoo." In Value Practices in the Life Sciences and Medicine, edited by Isabelle Dussauge, Claes-Fredrik Helgesson, and Francis Lee, 153-167. Oxford: Oxford University Press.

Ghiselin, Michael T. 1997. Metaphysics and the Origin of Species. Albany, NY: SUNY Press.

Grosz, Elizabeth. 2004. The Nick of Time: Politics, Evolution and the Untimely. Durham, NC: Duke University Press.

Haraway, Donna. 2008. When Species Meet. Minneapolis, MN: University of Minnesota Press.

- 2016. Staying with the Trouble: Making Kin in the Chthulucene. Durham, NC: Duke University Press.

Helm, Dieter. 2015. Natural Capital: Valuing the Planet. New Haven, CT: Yale University Press. 
Hetherington, Kevin. 2004. "Secondhandedness: Consumption, Disposal, and Absent Presence." Environment and Planning D: Society and Space 22(1): 157-173.

Hinchliffe, Steve. 2008. "Reconstituting Nature Conservation: Towards a Careful Political Ecology.” Geoforum 39(1): 88-97.

Hinchliffe, Steve, Matthew B. Kearnes, Monica Degen, and Sarah Whatmore. 2007. "Ecologies and Economies of Action-Sustainability, Calculations, and Other Things." Environment and Planning A 39(2): 260-282.

Hird, Myra. 2009. The Origins of Sociable Life: Evolution after Science Studies. London: Palgrave Macmillan.

Ingold, Tim. 2011. Being Alive: Essays on Movement, Knowledge and Description. London: Routledge.

—. 2012. "Toward an Ecology of Materials." Annual Review of Anthropology 41(1): 427-442.

IUCN (International Union for Conservation of Nature) Red List. no date. "Overview of the IUCN Red List". http://www.iucnredlist.org/about/ overview\#current_limitations, accessed 15 December 2016.

- Red List Committee. 2013. The IUCN Red List of Threatened Species $^{\mathrm{TM}}$ Strategic Plan 2013-2020. Version 1.0. Prepared by the IUCN Red List Committee. http://s3.amazonaws.com/iucnredlist-newcms/ staging/public/attachments/1607/red_list_strategic_plan_2013_2020.pdf, accessed 15 December 2016.

Juniper, Tony. 2013. What Has Nature Ever Done for Us? How Money Really Does Grow on Trees. London: Profile Books.

Latour, Bruno. 2016. "Why Gaia Is Not a God of Totality." Theory, Culture \& Society 0(0): 1-21. Online First.

Law, John, and Annemarie Mol. 2011. "Veterinary Realities: What Is Foot and Mouth Disease?" Sociologia Ruralis 51(1): 1-16.

Lemann, Nicholas. 2013. "When the Earth Moved: What Happened to the Environmental Movement?" The New Yorker, April 15. http:// www.newyorker.com/magazine/2013/04/15/when-the-earth-moved, accessed 15 December 2016.

Lockwood, Alex. 2012. "The Affective Legacy of Silent Spring." Environmental Humanities 1: 123-140.

Lorimer, Jamie. 2006. "What about the Nematodes? Taxonomic Partialities in the Scope of UK Biodiversity Conservation." Social \& Cultural Geography 7(4): 539-558.

- 2012. "Multinatural Geographies for the Anthropocene." Progress in Human Geography 36(5): 593-612.

- 2015. Wildife in the Anthropocene: Conservation after Nature. Minneapolis, MN: University of Minnesota Press.

Lorimer, Jamie, and Clemens Driessen. 2013. "Bovine Biopolitics and the Promise of Monsters in the Rewilding of Heck Cattle." Geoforum 48: 249-259.

Lulka, David. 2004. "Stabilizing the Herd: Fixing the Identity of Nonhumans." Environment and Planning D 22: 439-463. 
MacKenzie, Donald. 2006. An Engine, Not a Camera: How Financial Models Shape Markets. Cambridge, MA: MIT Press.

MacKenzie, Donald, Fabien Muniesa, and Lucia Siu. 2007. Do Economists Make Markets? On the Performativity of Economics. Princeton, NJ: Princeton University Press.

Marris, Emma. 2011. Rambunctious Garden: Saving Nature in a Post-Wild World. New York: Bloomsbury.

Massey, Doreen. 2005. For Space. London and Thousand Oaks, CA: SAGE.

Mitchell, Audra. 2016. "Beyond Biodiversity and Species: Problematizing Extinction." Theory, Culture \& Society 33(5): 23-42.

Mitchell, Timothy. 2002. Rule of Experts: Egypt, Techno-Politics, Modernity. Berkeley, CA: University of California Press.

Mol, Annemarie. 2002. The Body Multiple: Ontology in Medical Practice. Durham, NC: Duke University Press.

Muniesa, Fabien. 2014. The Provoked Economy Economic Reality and the Performative Turn. London: Routledge.

Robertson, Morgan. 2012. "Measurement and Alienation: Making a World of Ecosystem Services." Transactions of the Institute of British Geographers 37(3): 386-401.

Rome, Adam. 2013. The Genius of Earth Day: How a 1970 Teach-in Unexpectedly Made the First Green Generation. New York: Hill \& Wang.

Rose, Deborah Bird, and Thom van Dooren. 2011. "Guest Editors' Introduction: Unloved Others: Death of the Disregarded in the Time of Extinctions." Australian Humanities Review 50(May): 1-4.

Smith, Justin E. H. 2014. "The Great Extinction". The Chronicle of Higher Education, The Chronicle Review. http://www.chronicle.com/article/TheGreat-Extinction/146275/, accessed 20 September 2016.

Soulé, Michael, Michael Gilpin, William Conway, and Tom Foose. 1986. "The Millenium Ark: How Long a Voyage, How Many Staterooms, How Many Passengers?” Zoo Biology 5(2): 101-113.

Sullivan, Sian. 2013a. "Banking Nature? The Spectacular Financialisation of Environmental Conservation.” Antipode 45(1): 198-217.

- 2013b. "After the Green Rush? Biodiversity Offsets, Uranium Power and the 'calculus of Casualties' in Greening Growth." Human Geography 6(1): 80-101.

— 2014. "The Natural Capital Myth; or Will Accounting Save the World? Preliminary Thoughts on Nature, Finance and Values", LCSV Working Article Series, no. 3. Manchester: University of Manchester.

- 2017. "On 'natural capital', 'fairy-tales' and Ideology." Development and Change 48(2): 397-423.

Sullivan, Sian, and Mike Hannis. 2014. "Nets and Frames, Losses and Gains: Value Struggles in Engagements with Biodiversity Offsetting Policy in England.” LCSV Working Article Series, no. 5. Manchester: University of Manchester.

Takacs, David. 1996. The Idea of Biodiversity: Philosophies of Paradise. Baltimore, MD: Johns Hopkins University Press. 
Taylor, Dorceta E. 2016. The Rise of the American Conservation Movement: Power, Privilege, and Environmental Protection. Durham, NC: Duke University Press.

ten Kate, Kerry, and Michael Crowe. 2014. Biodiversity Offsets: Policy Options for Governments. An input paper for the IUCN Technical Study Group on Biodiversity Offsets. Gland, Switzerland: IUCN.

van Dooren, Thom. 2011. "Invasive Species in Penguin Worlds: An Ethical Taxonomy of Killing for Conservation." Conservation and Society 9: 286-298.

- 2014. Flight Ways: Life and Loss at the Edge of Extinction. New York: Columbia University Press.

- 2016. "Authentic Crows: Identity, Captivity and Emergent Forms of Life." Theory, Culture \& Society 33(2): 29-52.

Yusoff, Kathryn. 2010. "Biopolitical Economies and the Political Aesthetics of Climate Change.” Theory, Culture \& Society 27: 73-99.

- 2011. "The Valuation of Nature: The Natural Choice White Article." Radical Philosophy 170: 2-7.

Aurora Fredriksen is a Simon Research Fellow in Geography at the University of Manchester's School of Environment, Education and Development. Her research is concerned with more-than-human geographies of care, affect and assemblage in the empirical contexts of biodiversity conservation and other human relationships with wildlife and emplaced ecologies. She has previously explored similar themes in the empirical settings of contemporary practices of humanitarian and development aid. 